\title{
INICIATIVAS LOCAIS E LUTA CONTRA A POBREZA E A EXCLUSÃ̃o
}

ANDRÉ CARMO ${ }^{1}$

Initiative locales et lutte contre la pauvreté et l'exclusion é o resultado de um projecto de investigação financiado pelo fundo quebequense de investigação social e cultural, no quadro de uma acção lançada em 2006, subordinada ao tema "pobreza e exclusão social". Nesta obra colectiva, dirigida por Juan-Luis Klein e Christine Champagne, são apresentados os resultados de cerca de três anos de investigação sobre iniciativas locais, nomeadamente, a luta contra a pobreza e a exclusão levada a cabo por actores locais que mobilizam recursos provenientes da economia social. O enfoque nas iniciativas locais, deve-se ao facto de os autores considerarem que, nas mais das vezes, estas constituem a única forma de estes poderem ter um papel activo na luta contra a pobreza e a exclusão.

Um dos traços mais característicos do Quebeque é o dinamismo da sua sociedade civil. Assim, de entre os vários exemplos possíveis de iniciativas locais actualmente existentes nessa província canadiana, os autores seleccionaram dez para serem objecto de exame aprofundado. Apesar das diferenças, todas correspondem a iniciativas levadas a cabo por actores locais com o objectivo de melhorar as condições e a qualidade de vida dos cidadãos. O objectivo deste trabalho é explorar os aspectos mais importantes para o sucesso das iniciativas locais, ou seja, os factores responsáveis pela criação de uma dinâmica de reconversão sócio-económica das comunidades que lhes permite melhorar a qualidade e o nível de vida.

Esta investigação é motivada por uma (dupla) questão fundamental: podem as iniciativas locais baseadas na economia social inverter os processos que conduzem à pobreza e à exclusão? Podem elas assegurar às comunidades desvitalizadas uma maior acessibilidade aos recursos de produção ou distribuição de riqueza, permitindo melhorar as condições e a qualidade de vida dos cidadãos? Para delimitar com maior precisão a temática em estudo, os autores definiram também três questões complementares: i) qual o papel da economia social face aos processos de desvitalização territorial e de exclusão social? ii) que tipo de relação deve estabelecer-se entre a economia social e a acção estatal para favorecer o sucesso das iniciativas locais de luta contra a pobreza e a exclusão? iii) que forma deve ter o apoio estatal para promover o desenvolvimento de iniciativas locais cuja missão é contrariar e reverter os processos de desvitalização territorial ou a exclusão social? Assim formuladas, as questões a que o trabalho procura dar resposta denotam uma preocupação com os limites da acção

1 Investigador, CEG-UL. E-mail: carmo@campus.ul.pt 
desenvolvida pelas iniciativas locais, designadamente, o facto de estas não deverem ser vistas como substitutas da acção governamental e da economia privada. Pelo contrário, advoga-se que é na medida em que elas são capazes de mobilizar o Estado e o sector privado que as iniciativas locais são mais eficazes.

O livro está organizado em três partes. Na primeira, constituída por dois capítulos, são lançadas as bases conceptuais e analíticas consideradas necessárias para abordar a pobreza e a exclusão social. Em primeiro lugar, estabelecem-se os eixos de análise em torno da problemática territorial, de onde resultam as interrogações que acima referimos. São analisadas as fracturas territoriais e as polarizações que explicam o empobrecimento dos lugares e das comunidades locais. No segundo capítulo, aborda-se a evolução das definições e dos indicadores de pobreza e de exclusão tomando em linha de conta o contexto territorial (Quebeque) em que se inserem os casos de estudo. Examinando as múltiplas facetas da luta contra a pobreza, este capítulo incide sobre as características principais de novas formas de pobreza e exclusão.

A segunda parte integra cinco iniciativas locais existentes em Montreal que se inscrevem numa dinâmica particular marcada por um conjunto de dualidades urbanas (ricos vs pobres; maiorias $v s$ minorias culturais; incluídos $v s$ excluídos). No contexto metropolitano, pobreza e exclusão têm expressão quer ao nível individual (monoparentalidade, baixos rendimentos, imigração recente, etc.), quer ao nível colectivo (desindustrialização, bolsas de pobreza, fragilidade do tecido social, etc.). As cinco iniciativas locais mobilizam uma grande diversidade de recursos e de actores e assumem diferentes configurações, designadamente: i) o conselho local das intervenções comunitárias de Bourdeaux-Cartierville (CLIC), projecto de revitalização urbana integrada, baseado na concertação de diferentes actores locais, maioritariamente institucionais, responsáveis pelos diferentes projectos sectoriais relacionados com a habitação e os serviços; ii) o centro comunitário de lazer de Côte-des-Neiges, organismo que visa promover a integração social dos imigrantes residentes num bairro multiétnico através do voluntariado e da cultura; iii) a cozinha colectiva Hochelaga-Maisonneuve, entidade comunitária que contribui não apenas para o melhoramento da segurança alimentar e da empregabilidade dos participantes, através de medidas direccionadas para a inserção socio -profissional, mas também para a revitalização do próprio bairro; iv) o centro de alfabetização popular e inserção socioprofíssional N A RIVE em Rosemont-La Petite-Patrie, organização sem fins lucrativos especializada na formação e inserção social dos imigrantes recém-chegados, provenientes do Haiti; v) a associação 'Mulheres com poder', que procura criar um meio de vida adequado às jovens mães solteiras em situação de precariedade e vulnerabilidade social e profissional.

A terceira parte coloca o enfoque sobre cinco iniciativas locais em meios não metropolitanos (cidades médias e vilas rurais). No seu conjunto, estas iniciativas, confrontam-se com os efeitos e os desafios da passagem de uma economia baseada na exploração dos recursos naturais para uma outra centrada nos serviços e nas novas tecnologias. Os cinco casos apresentados são provenientes de duas regiões: Bas-Saint-Laurent (que apresenta problemas gerais de desenvolvimento socioeconómico) e Saguenay-Lac-Saint-Jean (muito dependente de uma economia ligada a um sector primário fortemente abalado pelo encerramento de indústrias e pela crise do sector da madeira). As iniciativas locais estudadas são: i) o grupo CODERR (corporação de desenvolvimento da reciclagem e da recuperação), localizado em Alma, Lac-Saint-Jean, organização sem fins lucrativos que tem como objectivo a recolha e gestão de resíduos, bem como a reciclagem de materiais usados; ii) a comunidade Sainte-Irène, cluster socioeconómico local, ou seja, que articula em rede quatro entidades locais (uma estação de esqui, uma organização sem fins lucrativos que opera no domínio florestal, 
uma cooperativa agrícola e uma cooperativa de serviços de proximidade); iii) a comunidade de Ferland-et-Boilleau, estratégia de desenvolvimento que combina e integra os projectos turísticos, florestais, agrícolas e de serviços; iv) o quadro de luta contra a pobreza de Chicoutimi, iniciativa que procura, sem realmente ter sucesso, mobilizar e congregar os actores institucionais do meio local para a luta contra a pobreza; v) a cooperativa de consumidores de Saint-Bruno-de-Kamouraska, que ilustra, pela sua ausência, a relevância das lideranças socialmente construídas, da coesão social e do sentimento de pertença territorial para o sucesso de projectos de desenvolvimento local.

As conclusões sugerem que, apesar de contribuir para a revitalização de meios locais e para a construção e mobilização de recursos comunitários, a partir dos quais se podem erigir projectos locais, a economia social, não pode, só por si, impedir o aprofundamento das tendências para o empobrecimento e a exclusão. Os actores devem promover estratégias plurais de desenvolvimento assentes numa articulação virtuosa entre economias pública e privada. A economia social e a acção comunitária devem ser vistas como trampolins e/ou incubadoras de iniciativas locais e não como mecanismos que possibilitam a redução do investimento estatal para o desenvolvimento local ou a desresponsabilização do Estado no que concerne à intervenção territorial.

Os casos mostram que o sucesso das iniciativas locais orientadas para o combate à pobreza e a exclusão depende da: i) existência de uma liderança socialmente construída; ii) capacidade dos líderes e dos actores locais para mobilizar uma grande diversidade de recursos endógenos e exógenos e de os combinar; iii) existência de instâncias e organizações que permitam regular localmente os conflitos entre os actores e aprender a agir colectivamente; iv) identificação colectiva de objectivos estratégicos destinados a usar os programas públicos e outras estruturas de apoio ao desenvolvimento das colectividades; v) construção de identidades positivas e de uma consciência territorial, favorecendo tanto o envolvimento dos actores no seio das suas comunidades como a capacidade de criação de riqueza.

Em suma, as iniciativas estudadas indicam que a luta territorial contra a pobreza e a exclusão deve incluir uma presença forte, mas flexível, do Estado. Por seu turno, esta presença deve traduzir-se na transferência ou redistribuição de recursos, mas também materializar-se na vontade e capacidade de facilitar a apropriação local, bem como o papel activo e concertado dos actores locais no lançamento de iniciativas de desenvolvimento. Em parceria com o Estado, a economia social pode ser considerada uma base essencial e eficaz para a mobilização cidadã, aspecto necessário e absolutamente crucial para o desenvolvimento.

i Klein J-L, Champagne C (dir.) (2011) Initiatives locales et lutte contre la pauvreté et l'exclusion. Presses de l'Université du Québec, Québec. 